PAEDAGOGIA CHRISTIANA

2/26(2010) - ISSN 1505-6872

Jarostaw Michalski*

Toruń

\title{
Plus ratio quam vis. Propozycja współczesnego dialogu edukacji z religią
}

Okres ponowoczesny związany z szybkimi przemianami ustrojowymi, obejmującymi zarówno sferę polityczną, społeczno-ekonomiczną, edukacyjną i cywilizacyjna, postawił przed człowiekiem wiele skomplikowanych problemów, dotyczących jego egzystencji. Dzisiaj nie ulega już wątpliwości, że nie jesteśmy przygotowani na nieprzejrzystość, ambiwalencję świata i porażki. Współczesny człowiek narażony jest na ciaggły stres i poczucie braku wpływu na własne życie. Dobrym przykładem są choćby - ostatnie, tragiczne wydarzenia, związane z katastrofą pod Smoleńskiem i śmiercią wielu osób. Każdego dnia człowiek staje wobec konieczności wyborów, które są tym trudniejsze, bo często nie znajdują wsparcia w przeszłości, w przykładach osób najbliższych i sam musi tworzyć własną tożsamość na „ruchomych piaskach". Wszystko to staje się szczególnego rodzaju powodem, by edukację, a przede wszystkim edukację religijną uczynić przedmiotem poważnego namysłu, zwłaszcza w kontekście wszechogarniającego pluralizmu (historycznego, społeczno-kulturowego etc.) ${ }^{1}$.

* Ks. dr hab. Jarosław Michalski, prof. UMK, kierownik Pracowni Pedagogiki Filozoficznej i Chrześcijańskiej na Wydziale Nauk Pedagogicznych Uniwersytetu Mikołaja Kopernika w Toruniu.

${ }^{1}$ Por. Z. Melosik, Modernizm i postmodernizm we współczesnym dyskursie humanistycznym: konfrontacje i kontrowersje, w: J. Gnitecki (red.), Pedagogika jako formacja intelektualna refleksji we wspótczesnym dyskursie humanistycznym, Poznań 2005, s. 21-50; K. Szafraniec, Człowiek wobec zmiany społecznej, Warszawa 1990; R. Schulz, Szkoła. Instytucja - systemrozwój, Toruń 1995; J. Żebrowski (red.), Edukacja a społeczeństwo obywatelskie, Gdańsk 1995. 
Niniejszy artykuł jest próbą zastanowienia się, z pozycji pedagoga, nad nowym rozumieniem wzajemnych związków edukacji i religii w naszej sytuacji historycznej, jest próbą odpowiedzi na pytanie, jak współcześnie powinna wyglądać edukacja religijna. Edukacja religijna, którą osobiście określam jako „wychodzącą od człowieka i zorientowaną na człowieka”, czyli taką, w której centralnym momentem procesu wychowawczego jest człowiek jako osoba. Edukacja religijna, która byłaby szansą na jego integralny rozwój.

Założenia takie przekreślają oczywiście, jako z gruntu fałszywe i nieuzasadnione, traktowanie relacji między religia a edukacją, a rozwojem człowieka jako alternatywy czy choćby dylematu. Wskazują na perspektywę religijną oraz pozwalają na konstruktywną dyskusję/dialog o możliwych drogach stawania się człowiekiem. Często bowiem we współczesnej myśli o wychowaniu się pojawia owa alternatywa, według której wprowadzenie do edukacji religii miałoby oznaczać rezygnację z programu wspierania rozwoju człowieka. Jak zauważa Katarzyna Olbrycht, jeśli „wspieranie rozwoju” uznać - w myśl współczesnych poglądów pedagogicznych, a także zgodnie z filozofią antywychowania - za alternatywę dla „wychowania tradycyjnego", opartego na przemocy wewnętrznej i zewnętrznej, religia (kojarzona $\mathrm{z}$ wychowaniem) i nowoczesne podejście do pracy z dzieckiem stanowiłyby dwa przeciwstawne bieguny stosunku do człowieka i jego rozwoju. Religia, kojarzona przez ideologów nowoczesnego wychowania z przymusem kulturowo-obyczajowym, bezwolnością, zgodą na represyjność, ćwiczeniem postaw adaptacyjnych, akceptacją irracjonalności, rzeczywiście byłaby nie do pogodzenia $\mathrm{z}$ wyzwoleniem $\mathrm{w}$ człowieku motywacji do rozwoju różnych jego potencjałów, do uwalniania się od presji zewnętrznej i wewnętrznej, do walki o własny autentyzm. Dyskusja, bardziej lub mniej jawnie zakładająca taką interpretację ścierających się stanowisk, zafałszowuje rzeczywistą sytuację i wymusza sztuczne wybory racji².

Celem edukacji religijnej ,wychodzącej od człowieka i na niego zorientowanej”, prowadzonej zarówno przez społeczeństwo, jak i przez pojedynczego wychowawcę, jest pomoc w kształtowaniu ,prawdziwych przekonań religijnych podtrzymywanych i wspieranych naturalnymi i autentycznymi motywacjami". Chodzi tu o zaoferowanie wychowankom konkretnej pomocy umożliwiającej, krok po kroku, dokonanie ostatecznych decyzji, które staną się bazą ich życia, fundamentem ich integralnego rozwoju.

${ }^{2}$ K. Olbrycht, Religia a wspieranie rozwoju człowieka, w: Z. Zdybicka (red.), Religia a sens bycia człowiekiem, Lublin 1994, s. 103-104; por. J. Michalski, Edukacja i religia jako źródła rozwoju egzystencjalno-kognitywnego. Studium hermeneutyczno-krytyczne, Toruń 2004, s. 21-42. 
Wydaje się bowiem, o czym pisze między innymi włoski psycholog i pedagog Franco Imoda, iż ,jedynie wiara, która przeszła przez krytykę głębokich motywacji, ma możliwość przetrwania i wspierania rozwoju człowieka; jedynie chrześcijaństwo, oparte na głębokich przekonaniach bez uwzględniania tylko zwykłych uzewnętrznianych tradycji lub masowych manifestacji, ma szansę przeżycia"3. Tak rozumiana edukacja bazuje z jednej strony na niepodważalnym fakcie istnienia religii oraz na szczególnej, dialogicznej relacji między nią a osobą ludzką i pozwala na wskazanie dróg (metod) wychowawczych, które do niej prowadzą.

Całość rozważań zawarta jest $\mathrm{w}$ dwóch zasadniczych częściach. W pierwszej części przedstawiony zostanie problem szczególnej relacji między religią a osobą ludzką. Na bazie tych rozważań ukazane zostana, w części kolejnej, obszary oddziaływań edukacyjnych (ze szczególną rolą dialogu), kształtujących dojrzałą religijność, która pozwoli być fundamentem integralnego rozwoju człowieka.

W prezentowanym tekście będę poszukiwał odpowiedzi na powyżej określone problemy. Chciałbym jednak zaznaczyć, a jednocześnie prosić, aby ten artykuł potraktować jako otwarte zaproszenie do namysłu nad sygnalizowanym przeze mnie problemem, a nie jakąś gotową koncepcję, jakiś zestaw gotowych (ostatecznych) odpowiedzi.

U podstaw prezentowanej przeze mnie propozycji - co zresztą zawarte jest w pierwszej części tytułu - leży słynna sentencja autorstwa wielkiego uczonego Pawła Włodkowica, którą później przejęło wiele uniwersytetów europejskich jako dewizę swojej działalności akademickiej - dewiza, która brzmi: Plus ratio quam vis. Co w dosłownym tłumaczeniu oznacza: „Więcej rozumu, prawdy niż siły czy przemocy”. Należy jednak pamiętać, że pierwotne znaczenie tego hasła odnosiło się do chrystianizacji Litwy, która miała być prowadzona metodą pokojowego głoszenia Ewangelii, a nie wymuszana ogniem i mieczem. Dzięki małżeństwu królowej Jadwigi z Władysławem Jagiełła, przywódcą pogańskiego ludu Litwinów, powstała partnerska wspólnota narodów w postaci unii, w której oba narody zachowały własną kulturę i tożsamość, a równocześnie były złączone wspólnym losem. Pod koniec XIV wieku taka wizja unii nie była powszechnie akceptowana. Krzyżacy nie chcieli uznać chrystianizacji Litwinów poprzez małżeństwo Jadwigi z Jagiełłą i poprzez późniejszą pokojową działalność misyjną. Twierdzili, że warunkiem chrystianizacji Litwy jest jej ujarzmienie. W pewnym sensie uważali, że Litwini, aby stać się chrześcijanami, najpierw muszą stać się Niemcami. Zasada Plus ratio quam vis zawiera uznanie prawa Litwinów (a w ogólniejszym ujęciu wszystkich ludów) do przyjęcia chrztu bez ko-

\footnotetext{
${ }^{3}$ F. Imoda, Sviluppo umano, psicologia e mistero, Alessandria 1993, s. 13.
} 
nieczności wyzbywania się własnej tożsamości narodowej. Chrześcijaństwo przekracza każdą kulturę, w której jest z konieczności ucieleśnione, tak więc każdy naród może przyjmować chrześcijańskie zbawienie, pogłębiając, a nie odrzucając własną tożsamość. W XVI wieku zasada ta nabrała innego znaczenia historycznego. Na tle Europy targanej wojnami religijnymi pomiędzy katolikami a protestantami Plus ratio quam vis oznaczało ekumeniczną strategię przywracania jedności Kościoła na drodze teologicznej dyskusji - dialogu, a nie metodą siłowego nawracania dysydentów ${ }^{4}$. Ta sama dewiza może być cenną wskazówką dzisiaj, kiedy zmagamy się z kryzysem wzajemnych relacji między religią a edukacją i poszukujemy odpowiednich fundamentów edukacji religijnej.

Co dokładnie znaczy Plus ratio quam vis? U podstaw tej sentencji bez trudu odnajdziemy antropologiczne rozumienie ludzkiej natury. Człowiek jest istotą rozumną i wolną (łac. ens intelligens et liberum). Jako taki ma zadanie - a zarazem możliwość - rozpoznawania prawdy i działania zgodnie z prawdą. Oczywiście człowiek, podobnie jak zwierzęta, ma ciało; znajduje się więc pod presją namiętności, które mogą nim kierować, zakłócając a niekiedy wręcz uniemożliwiając, wydanie racjonalnego sądu. Człowiekiem można kierować, podobnie jak kieruje się zwierzętami, czyli stosując metodę „kija i marchewki” - metodę straszenia karą i obiecywania przyjemności. Tak więc istnieją dwa odmienne sposoby wpływania na ludzi: jeden odwołuje się do ich „Zwierzęcej” natury, drugi zaś do ich człowieczeństwa. A zatem słowo vis należy odczytywać nie tylko jako zapowiedź bezpośredniego użycia siły, ale także i równocześnie jako umocnienie bądź osłabienie woli człowieka przez oddziaływanie na niego przyjemności odłączonej od prawdy. W tradycji filozofii arystotelesowskiej ten pierwszy model odpowiada sposobowi traktowania niewolników, drugi zaś stanowi wzór kierowania ludźmi wolnymi i otwartymi na dialog. Żeby skłonić ludzi do wybierania jedności na sposób wolny, trzeba znaleźć dobro, które będzie celem wszystkich ludzi, dobrem wspólnym. W imię takiego wspólnego dobra można przekonywać niepowtarzalne, niezależne i wolne istoty ludzkie do wspólnego działania jako członków wspólnoty. Dzięki temu odniesieniu do dobra wspólnego powstaje ludzka, otwarta na wszystkich wspólnota.

Jakość tej wspólnoty zależy oczywiście od jakości dobra wspólnego, z którego ona wyrasta. Najpełniejsza ludzka wspólnota wyrasta nie z jakiegoś szczególnego wspólnego dobra, ale z tego dobra, którym jest ludzkość sama w sobie. Istnieje hierarchia wspólnot zależna od rodzaju więzi tworzącej daną wspólnotę. Celem najdoskonalszej wspólnoty jest rozwój wspólnego

${ }^{4}$ R. Buttiglione, Plus ratio quam vis. Koncepcja demokracji na progu XXI wieku, „Ethos” 69-70 (2005), s. 441-449. 
człowieczeństwa, a więc wspólne rozwijanie się rozumnych i wolnych istot ludzkich. U podstaw takiej doskonałej wspólnoty leży wolność i prawda ${ }^{5}$.

\section{Religia a osoba ludzka}

Relację religia a osoba ludzka można by określić jako relację zachodzącą między autorytetem Boga a wolnością człowieka. Dla rozstrzygnięcia tego zagadnienia trzeba bliżej określić charakter autonomii sumienia, czyli wolności człowieka. Skoro sumienie jest sądem rozumu, a więc aktem poznawczym stwierdzającym prawdę o dobru, które należy czynić, to w samej istocie sumienia zawsze jest odniesienie do prawdy. Autonomia sumienia nie jest więc absolutną twórczością w zakresie ustalania powinności działania i jego ukierunkowania. Tworzy się raczej poprzez właściwe odniesienie osoby ludzkiej do prawdy o sobie i otaczającej ją rzeczywistości. Prawda ta musi być uwzględniana w moralnym działaniu człowieka, będącym działaniem w świecie osób i rzeczy ${ }^{6}$.

Z sumieniem człowieka nierozerwalnie związana jest jego moralność. Jej analiza na płaszczyźnie czysto neutralnej ujawnia konieczność odniesienia osoby ludzkiej do Boga. Dzieje się to wówczas, gdy chcemy wskazać na ostateczne podstawy ontyczne norm moralnych czy odpowiedzialności człowieka. Religia zmienia perspektywy. Od razu ustawia człowieka do Boga. Jeśli przez religię rozumiemy stosunek człowieka do Boga, który opiera się w człowieku na jego naturze osobowej, a więc rozumnej i wolnej, to religia jest czymś istotowo osobowym i ze swej natury nie powinna naruszać charakteru życia moralnego, świadomego i wolnego, kierowanego i ocenianego przez akt sumienia ${ }^{7}$.

W nowej relacji człowieka do Boga, jaką ujawnia religia, obowiązuje ta sama zasada, jaka obowiązuje w całym życiu moralnym człowieka. Jest nią zasada posłuszeństwa w sumieniu. Można więc powiedzieć, że każdy akt religijny jest aktem moralnym, osobowym, ludzkim, a autonomia sumienia kształtowana jest tu także poprzez relację do prawdy ${ }^{8}$.

5 Tamże, s. 442; por. R. Guardini, Sorge um den Menschen, Würzburg 1962; J. Michalski, dz. cyt., s. 21-42.

${ }^{6}$ K. Wojtyła, Osoba i czyn, Kraków 1969, s. 163.

7 Por. tamże; T. Styczeń, Solidarność wyzwala, Lublin 1993, s. 29-56; tenże, Gewissenautonomie und Norm, w: F. Brend (red.), Busse-Umkehr Formen der Vergebung. Referate der „Internationalen Theologischen Sommerakademie 1991” der Linzer Priesterkreises in Aigen, Steyr 1992, s. 191-218.

8 Por. Z.Zdybicka, Religia i religioznawstwo, Lublin 1992, s. 202n; J. Michalski, dz. cyt., s. 135-136. 
Religia w tym zakresie wnosi do życia człowieka dwa istotne momenty:

- ukazuje nowe dziedziny rzeczywistości, przez co poszerza domenę prawdy;

- suponuje nowy charakter afirmacji prawd, które nie są poznawane wprost, a dostępne są jedynie na mocy zawierzenia autorytetowi Boga - na mocy wiary ${ }^{9}$.

Jeśli autonomia sumienia, a w konsekwencji autonomia osoby ludzkiej, jej wolność, buduje się w relacji do prawdy i jeśli człowiek buduje swoje postępowanie, opierając się na poznaniu, to im lepiej poznaje, im bliższy jest prawdy o sobie i rzeczywistości, tym jest wolniejszy. W tej perspektywie religia nie tylko nie zagraża autonomii sumienia i wolności człowieka, lecz ją poszerza.

Religia wskazuje więc na nowe horyzonty życia ludzkiego, poszerza dziedzinę ludzkich możliwości i wolnych decyzji. Jeśli więc obecnie tak wiele mówi się o ograniczeniu człowieka przez religię, to wynika to często $\mathrm{z}$ nieznajomości prawdziwych dróg wolności, a może płynać także z pewnych deformacji w myśleniu człowieka czy praktykowaniu religii ${ }^{10}$.

Religia rozważana od strony człowieka nie ogranicza się tylko do więzi indywidualnej ,,ja-Ty”. Człowiek bowiem swój związek z Bogiem przeżywa społecznie, wspólnotowo. Tak jak w wymiarze jednostkowym związek osoby ludzkiej z Bogiem przyczynia się do jej personalizacji, tak też w wymiarze społecznym do jej socjalizacji. W tym znaczeniu społeczne przeżywanie więzi z Bogiem jest socjotwórcze. Stwarza więc nowe relacje interpersonalne, cementuje religijny byt społeczny, czyni go wspólnotowym podmiotem wobec Boga. Określa też jego bytowanie, możliwości i warunki społecznego stawania się, rozwoju i dopełnienia. Wyznacza ostateczny cel wszelkich aspiracji, dążeń ludzkich i działań. Tym samym czyni je bardziej sensownymi, ukazując finalne spełnienie się bytu społecznego, osoby społecznej, którą tworzy i buduje religia ${ }^{11}$.

Przeżywana przez człowieka więź z Bogiem, zarówno w wymiarze indywidualnym, jak i społecznym, chociaż koncentruje się na intymnej sferze wewnętrznej, to jednak nie tylko do niej się sprowadza. Religia ma też swój zewnętrzny wyraz i kształt. Inspiruje przez swoją zewnętrzność do twórczych działań osobowych i społecznych, do doskonalenia się, co znajduje swój wyraz w tworzeniu wartości osobowych i ludzkich o charakterze reli-

9 Por. tamże; R. Cipriani, La religione diffusa, Roma 1988.

${ }^{10}$ Por. E. Ciupak, Religia i religijność, Warszawa 1982, s. 39n; A. Exeler, Religiöse Erziehung als Hilfe zur Menschwerdung, München 1982; J. Michalski, Wartości w procesie wychowania. Znaczenie i konieczność, „Forum Oświatowe” 1/32 (2005), s. 47-69.

${ }^{11}$ Por. F. Garelli, Forza della religine e debolezza della fede, Bologna 1998, s. 86n. 
gijnym, w przemianie życia, współuczestniczeniu w kreatywnej i zbawczej działalności Boga. W tym znaczeniu religia jest wartością niezbywalną w życiu człowieka i społeczności ludzkiej ${ }^{12}$. Religia jest więc rzeczywistością specyficzną i oryginalną. Nie można jej sprowadzić ani do poszczególnych działów kultury, ani do niej samej. Pozostaje w rozlicznych związkach z całą rzeczywistością doczesną, którą przenika, w której się wyraża, w której nie da się zamknaćc. Posiada wymiar historyczny, łączy ludzkie z boskim, człowieka z Bogiem. Koncentruje się na osobie ludzkiej, przejawia się i wyraża w jej postawie i działaniach. Jednakże nawet i w tym wymiarze, chociaż jest w znacznym stopniu zobiektywizowana, dostępna do badań, to i tak jawi się jako rzeczywistość tajemnicza, misteryjna, głęboka, tak jak jest nią osoba ludzka, nie do końca poznawalna w swoich wyborach, dążeniach, postawie, życiu.

Ten aspekt religii uwidocznia się szczególnie, gdy rozpatruje się jej stronę przedmiotową którą stanowi Bóg. Jakkolwiek manifestuje On swą obecność w historii i wezwaniu skierowanym do człowieka w znakach, staje się osnową życia religijnego człowieka, to i wówczas nie jest poznawany do końca, w głębi Jego bytu i wielkości. W związku z tym religia jawi się jako rzeczywistość misteryjna łączności człowieka z Bogiem.

W tym kontekście wiele aktualnie funkcjonujących wcześniej definicji religii jest nieuprawnionych, gdyż zakładają one, że w sposób naukowy, empiryczny można całkowicie poznać i wyjaśnić fenomen religii. Wadliwe są zwłaszcza redukcjonistyczne próby jej ujęcia. Nie zakładają one bowiem rozumienia religii jako osobowej więzi człowieka z Bogiem, lecz podkreślają wytwory człowieka, a te nie mogą stanowić religii ${ }^{13}$.

\section{Edukacja $w$ dialogu $\mathrm{z}$ religią - szansą na integralny rozwój czlowieka}

Obecnie coraz częściej poszukuje się uniwersalnego sposobu wychowania, służącego integralnemu rozwojowi osoby ludzkiej. Doświadczenie pokazuje bowiem, że zarówno wychowanie jednostki do zachowania określonych form postępowania przez ćwiczenie i powtarzanie różnych czynności, ani wychowanie polegające na przyjęciu określonych postaw i wartości, ani wreszcie autorytatywna postawa wychowawcy, która zabija inicjatywę i samodzielność wychowanka, dziś już nie zadowalają i często okazują się niewystarczające.

${ }_{12}$ M. Rusecki, Istota i geneza religii, Warszawa 1989, s. 144.

${ }^{13}$ Por. Z. Zdybicka, dz. cyt., s. 199n. 
Niewątpliwie, jedną z propozycji rozwiązywania problemu jest edukacja religijna. Chcąc jednak odpowiedzieć na pytanie, jak wychowywać i do czego wychowywać, należałoby przedtem zastanowić się, kim jest człowiek jako przedmiot wychowania.

Jest z pewnością osobą, podmiotem mówienia, wyrażania się, autokreacji, komunikowania, doświadczania, odniesienia, przeżywania. Jest czymś niepowtarzalnym, gdyż posiada określoną i jedyną swego rodzaju tożsamość, identyczność. Cechuje go naturalne odniesienie do otaczającej rzeczywistości, do samego siebie i wartości najwyższej, to jest Boga. Wynika stąd, że w procesie wychowania powinno się uwzględniać wszystkie wymiary osobowości człowieka: fizyczny, psychofizyczny i duchowy. Podstawą wychowania będzie zatem nie tylko kształtowanie człowieka obejmujące wymienione strefy, ale przede wszystkim pomoc i wspieranie jego dynamicznego rozwoju z uwzględnieniem naturalnych predyspozycji, uzdolnień, talentów, wiedzy. W kontekście wychowania religijnego będzie to też rozwój predyspozycji, będących wynikiem wartości nadprzyrodzonych. Zatem wysiłek ludzki, dotyczący wszechstronnego wychowania, powinien w tym przypadku być wspierany laską Bożą (pochodzącą od Boga). Edukacja religijna, religia i właściwy tylko jej system wartości może i często odgrywa rolę w rozwoju, wychowaniu i formowaniu postaw wychowanka względem siebie, świata i innych.

Całościowe spojrzenie na wychowanie wymaga uwzględnienia najistotniejszych jego elementów składowych, to jest religijności i moralności. Religijność jest najczęściej definiowana jako indywidualny i subiektywny stosunek człowieka do Boga, regulowany określonymi nakazami, prawdami, twierdzeniami, wynikającymi z założeń danej religii. Dojrzała forma religijności ułatwia każdemu człowiekowi prawidłowy rozwój osobowości, określenie relacji do transcendencji, do innych osób, do samego siebie i całego otaczającego świata, stąd ma tak istotny wpływ na kształt wychowania ${ }^{14}$.

Każdy człowiek tworzy sobie własną religijność, uzależnioną od własnych potrzeb, przy współudziale różnych sfer swojego życia, to jest rozu$\mathrm{mu}$, woli, emocji itp. Dlatego też między innymi nie jest ona jednakowa dla wszystkich ludzi. Na kształt religijności wpływa również całe dziedzictwo kulturowe, znaki, symbole, doświadczenia, zachowania wypływające z relacji do tego, co transcendentne, co nie jest też dostępne bezpośredniemu

${ }^{14}$ Por. Z. Chlewiński, Dojrzałość, osobowość, sumienie, religijność, Poznań 1991, s. 85n; W. Piwowarski, Religia jako wartość wspólna i osobowa, „Przegląd Humanistyczny” 5/38 (1994), s. 53-61; R. Köcher, Die Entwicklung von Religiosität und Kirchlichkeit seit dem Zweiten Weltkrieg bis heute, „Diakonia” 19 (1988), s. 35-39. 
poznaniu ${ }^{15}$. A wszystko to dokonuje się głównie w procesie wychowania, podczas którego istotną rolę odgrywają przyjęte przez środowisko czy instytucje religijne pojęcia, a przede wszystkim koncepcja bóstwa. Wydaje się jednak, iż w dojrzałości religijnej szczególnego znaczenia nabiera indywidualne doświadczenie związane $\mathrm{z}$ różnymi etapami wzrostu. Można tu wymienić następujące etapy: dzieciństwo (do 12 roku życia); młodość (12-16 rok życia i 16-24 rok życia); dojrzałość (25-60 rok życia); starość (po 60 roku życia).

Najważniejszym czynnikiem warunkującym prawidłowy rozwój dojrzałości jest oczywiście atmosfera życia rodzinnego, miłość, wzajemne zaufanie, autentyczne przeżycia religijne, w których dziecko uczestniczy. Bezkrytyczne przyjmowanie tego, co się wcześniej przyjęło od rodziców, przechodzi jednak w konfrontację z chwilą rozwoju zdolności myślenia abstrakcyjnego i rozwoju umysłowego. Jest to pierwszy symptom wejścia w nowy etap dojrzałości religijnej. Jednakże pełna niezależność nie tylko myślenia, ale i działania pojawia się w wieku 16-18 lat. Młodzi ludzie zaczynają wyzwalać się spod autorytetów (głównie rodziców) i tworzyć własny obraz rzeczywistości. Jest to okres szczególnych kryzysów religijnych i moralnych rodzących wątpliwości, a często utratę wiary ${ }^{16}$.

Kryzysy uwarunkowane są różnymi czynnikami, zwłaszcza środowiskowymi i osobowościowymi jednostki (inteligencja, emocjonalność, religijność przedkryzysowa, samodzielność myślenia i działania, refleksyjność). Ponadto znaczny wpływ na rozwój kryzysu może mieć przeżywanie własnej płciowości i erotyzmu, które stawiają przed młodymi ludźmi pewne wymagania i ograniczenia. W usprawiedliwieniu własnych zaniedbań religijnych młodzi ludzie przerzucają swoją niechęć do zakazów właśnie na wiarę i religię ${ }^{17}$.

Znaczącym czynnikiem kryzysotwórczym jest atomizacja współczesnego życia. Ciagły pośpiech, pęd, technicyzacja ograniczają czas na przemyślenie własnego życia, jego celu i sensu, jak również swojej relacji do Boga. Prowadzi to nierzadko do nadużyć w sferze przeżyć zmysłowych oraz

${ }_{15}$ Por. F. Heiler, Le religioni dell 'umanità, Milano 1985; Z. Ziółkowski, Z zagadnień dojrzałości religijnej, „Znak” 210 (1971), s. 1587-1594; Z. Płużek, A. Jacyniak, Świat ludzkich kryzysów, Kraków 1996, s. 47-49.

16 Por. Cz. Walesa, Rozwój religijności człowieka, w: Z. Chlewiński (red.), Psychologia religii, Lublin 1982, s. 153-173; J. W. Fowler, Stages of Faith. The Psychology of Human Development and the Quest for Meaning, San Francisco 1981; F. Głód, Psychologiczna analiza kryzysów religijnych ludzi dorostych, w: K. Majdański (red.), Rozwój człowieka w modlitwie, Warszawa 1982, s. 53-54; zob. Z. Trenti, L'esperienza religiosa, Torino 1999, s. 105-124.

17 Por. W. Prężyna, Kształtowanie się życia religijnego, „Znak” 210 (1971), s. 1575-1586; tenże, Symptomy dojrzałej religijności, w: W. Turek, J. Mariański (red.), Kościót w stużbie czlowieka, Olsztyn 1997, s. 269-278. 
do szukania kompensacji w uzależnieniach (alkohol, narkotyki) ${ }^{18}$. Wpływa to w sposób znaczący na osłabienie wiary i pojawienie się kryzysu moralnego. Sprzyja mu nagłe odkrycie innego, fascynującego i pozornie lepszego systemu wartości, hipokryzja autorytetów, wejście w nowe środowisko, doświadczenie krzywdy lub zła, ocena dotychczasowej własnej moralności jako niewłaściwej itd.

Jednakże kryzysy moralne są szansą na zmianę pozytywną, uzależnioną znacznie od ukształtowanego genetycznie i środowiskowo sumienia. Za kryterium rozwoju sumienia Z. Chlewiński przyjmuje „rozwój psychiczny struktur poznawczo-oceniających, dzięki którym jednostka zna i uznaje za własne reguły moralne oraz rozwój odpowiednio z nimi sprzężonych reakcji emocjonalnych, ostrzegających przed naruszeniem reguł moralnych, karzących w przypadku popełnienia zła, bądź satysfakcjonujących w przypadku zrealizowania czynu dobrego"19. W taki sposób sumienie staje się wykładnikiem wychowania, samowychowania i samooceny. Dzięki jego istnieniu człowiek może kontrolować własne zamierzenia i osiagnąć autonomię w swoich moralnych decyzjach ${ }^{20}$.

Czynnikiem warunkującym prawidłowy rozwój sumienia, wychowania moralnego i wychowania religijnego jest przede wszystkim oddziaływanie rodziny we wszystkich latach życia dziecka. W zależności od typologii rodziny $^{21}$ (rodzina wzorowa, normalna, wydolna, niewydolna, patologiczna) może ona regulować podatność dziecka na wpływ środowiska zarówno negatywnie, jak i pozytywnie. Jednakże zróżnicowanie typów może wpływać w młodszym wieku na samodzielną refleksję, chęć porównania, dążenia do lepszego życia, do niwelowania czynników hamujących wewnętrzny i zewnętrzny rozwój. Młody człowiek staje się przez to coraz bardziej świadomy konieczności dokonywania selekcji i wyborów, co ma ogromne znaczenie dla rozwoju osobistej autonomii ${ }^{22}$.

Pod wpływem uświadomienia sobie własnych (różnego typu) kompetencji młody człowiek nabiera poczucia współuczestniczenia w życiu i osobistej pełnowartościowości. Jest to bardzo istotne z punktu widzenia rozwoju dojrzałego sumienia, które w sposób bezpośredni wiąże się z dojrzałością do wychowania religijnego ${ }^{23}$.

18 Por. H. Franta, Individualità e formazione integrale, Roma 1982; F. Bednarski, Wychowanie młodzieży dorastajacej, Roma 1976.

19 Z. Chlewiński, dz. cyt., s. 74.

${ }^{20}$ Por. G. Allport, Osobowość i religia, Warszawa 1988, s. 58-64.

${ }^{21}$ Por. S. Kawula, Próba pedagogicznej typologizacji rodzin, w: S. Kawula, J. Bragiel, A. Janke (red.), Pedagogika rodziny, Toruń 1997, s. 153-174.

${ }^{22}$ B. Hołyst, System wartości i zdrowie psychiczne, Warszawa 1990, s. 14.

${ }^{23}$ Por. C. Fiore, Etica per giovani. Appunti e spunti per una educazione morale, Torino 1998. 
Dużą rolę w formowaniu sumienia odgrywa budzenie u młodzieży świadomości, iż podlega ona różnym wpływom zewnętrznym (np. środowisko, media), manipulującym ich wyborami i przyjmowanymi postawami. Manipulacja ta wytwarza w świadomości swych odbiorców dwojakiego rodzaju efekty i przekonania. Po pierwsze, że rzeczywistość, np. moralna, jest taka, jaką im się przedstawia, i po drugie, że reakcja na tę rzeczywistość zależy od postawy samego człowieka, będącego w istocie obiektem manipulacji. Ważne jest, aby młody człowiek uświadomił siebie, na ile treści te wpływają na jego poglądy, przekonania czy sposoby wartościowania. Od tego bowiem zależy jego autonomia sumienia i niezależność myślenia ${ }^{24}$.

W wychowaniu zatem chodzi przede wszystkim o kształtowanie postaw odważnych, otwartych, autentycznych, niezależnych. Osiąganie takiej autonomii sprzyja wyzbywaniu się lęków, różnicowaniu wartości, przeżywaniu własnej wewnętrznej wolności, która ściśle wiąże się z odpowiedzialnością za rozwój własnej osobowości wiernej swoim przekonaniom.

W wychowaniu moralnym i kształtowaniu dojrzałej religijności najistotniejszą sprawą staje się więc nauka dokonywania własnych wyborów i właściwego moralnego oceniania oraz odkrywania prawdziwych wartości. Umiejętność ta może mieć duże znaczenie w rozwiązywaniu kryzysów religijnych, które niekoniecznie muszą kończyć się zobojętnieniem religijnym.

Edukacja religijna, która wydaje się być podstawą w pokonywaniu wszelkich trudności, powinna być ukierunkowana na rozwój następujących czynników:

a) autonomii motywacji religijnej;

b) antropomorficznej koncepcji Boga;

c) umiejętności rozróżniania elementów istotnych w religii i przypadkowo z nią związanych;

d) umiejętności rozwiązywania kryzysów religijnych;

e) autentyczności przekonań religijnych.

Ad. a) Motywy postępowania człowieka nie zawsze są uświadomione i rozpoznane. Dojrzała motywacja czerpie początki z wczesnych doświadczeń, choć nie musi z nich wynikać. Motywacja religijna, będąc autonomiczna, jest przejawem dojrzałej religijności, która nie może być jednak mechanizmem obronnym. Wówczas bowiem nie jest dojrzała. Chodzi tu przede wszystkim o kształtowanie takiej motywacji, która wskazuje na wartości religijne będące istotą dla nich samych, a nie jako ucieczka przed lękiem, beznadziejnością czy załamaniem.

Ad. b) Nierzadko dorosły człowiek tworzy sobie fałszywy obraz Boga, zależny od jego możliwości intelektualno-moralnych. Tymczasem w wycho-

24 Por. Z. Chlewiński, dz. cyt., s. 89-107. 
waniu religijnym chodzi o stworzenie obrazu Boga prawdziwego i transcendentnego, obrazu ponad wszelkimi pojęciami i wyobrażeniami. Dzięki refleksji możliwa jest korekcja swego myślenia, a tym samym kształtowanie dojrzałego obrazu Boga.

Ad. c) Bardzo ważna jest też umiejętność odróżniania w religii jej elementów istotnych i przypadkowych. Dotyczy to przede wszystkim moralnych zobowiązań człowieka religijnego.

Ad. d) Rozwój religijności związany jest oczywiście z kryzysami. Sposoby ich pokonywania mogą okazywać się twórcze i wpływać pozytywnie na jednostkę. Uczy się ona wówczas poznawać siebie, nazywać problemy, zwracać się do innych o pomoc.

Ad. e) Przekonania religijne dotyczą przede wszystkim rzeczywistości transcendentnej. Chodzi tu o osiagnięcie świadomości, że wiara wiąże się głównie z decyzją pełną zaufania, akceptującą system wartości motywujący do działania. Przyjęcie prawd religijnych musi być świadome, przemyślane, zrozumiane i poddane wewnętrznej ocenie ${ }^{25}$.

Powyższe rozważania pozwalają na sformułowanie wniosku, że dojrzałość religijna, osiagana w procesie wychowania, odgrywa niepoślednią rolę w rozwoju jednostki i w ostatecznym efekcie prowadzi do wszechstronnego jej spełnienia i dojrzałej osobowości.

W istocie dwie sfery: religijność i osobowość wzajemnie się warunkują w swoim dynamicznym rozwoju. Religijność wpływa na zakres i strukturę, integrację wartości, które z kolei modyfikują i ukierunkowują osobowość. Ta natomiast wzmacnia $\mathrm{w}$ jednostce poczucie godności i rodzi zaufanie do własnych możliwości etycznych. Z kolei predyspozycje osobowościowe w znacznym stopniu kształtują zjawisko religijności. Dojrzała i zintegrowana religijność zakłada zdrową i w pełni rozwiniętą, dobrze funkcjonującą osobowość człowieka ${ }^{26}$.

\section{Podsumowanie: edukacja religijna w dobie pluralizmu}

W ostatnich kilkunastu latach wykonano wiele badań, w świetle których Polskę, obok Irlandii, można zaliczyć do najbardziej religijnych krajów Eu-

${ }^{25}$ Tamże; por. K. Popielski, Doświadczenie sensu i jego znaczenie dla egzystencji, w: tenże (red.), Człowiek-wartości - sens. Studia z psychologii egzystencji, Lublin 1996, s. 55-60.

${ }^{26}$ Por. tenże, Rola religii w funkcjonowaniu osobowości, w: tenże, (red.), Psychologia religii, Lublin 1982; L. Feuerbach, Das Wesen der Religion, Heidelberg 1983; K. Popielski, Noetyczny wymiar osobowości. Psychologiczna analiza poczucia sensu życia, Lublin 1994, s. 128-140; D. Rumpf, Bildung und Religion, Hildesheim 1997, s. 85-83; T. Borowska, Pedagogia ograniczeń ludzkiej egzystencji, Warszawa 1998, s. 41-60. 
ropy $^{27}$. Tę uprzywilejowaną pozycję zapewniliśmy sobie, uzyskując w większości przyjętych w badaniach wskaźników religijności pierwsze miejsce. Dotyczyło to również wychowania religijnego, instytucjonalnego i w domu rodzinnym. Moglibyśmy być z tego faktu niezwykle usatysfakcjonowani, gdyby aktualnie dostępne metody badań i współczesny język nauki opisywałyby w prosty i przekonywujący sposób doświadczenie sacrum. Oznacza to, że nawet najbardziej rzetelne badania niewiele mówią o rzeczywistej religijności społeczeństwa, podobnie jak nasze przekonania religijne są o wiele bardziej złożone, niż wskazywałoby na to oficjalne deklaracje.

Opinie na temat polskiej religijności i wychowania religijnego są skrajne, zarówno wśród osób świeckich, jak i duchowieństwa. Przypomnijmy wypowiedzi ks. Józefa Tischnera: „Jestem przekonany, że wchodzimy dziś w Polsce w kryzys wiary, jaki nie miał sobie równego. Polski katolicyzm znalazł się w stanie trudnej do ukrycia depresji. Wynika ona z przekonania, że pogłębia się przepaść między Kościołem a biegiem spraw publicznych”28. Tischner charakteryzuje Kościół polski, jako Kościół „schorowanej wyobraźni” ze względu na jego partykularyzm a nie powszechność, jego ideologię religijną, a nie apostolskość, za to, że nie jest Kościołem łaski, a raczej Kościołem moralnych potępień ${ }^{29}$.

$\mathrm{W}$ dużej mierze bierze się to $\mathrm{z}$ niedostatku właśnie wychowania religijnego w domu rodzinnym oraz z indywidualnej i selektywnej religijności. Oznacza to, że wybieramy sobie dowolne przykazania do przestrzegania, prawdy do wierzenia i w konsekwencji nie czujemy się dostatecznie odpowiedzialni za siebie i innych. Nasza wiedza bardziej manifestuje się w praktykowaniu zwyczajów i obrzędów religijnych związanych ze świętami, które nabierają często cech pogańskich ${ }^{30}$.

Zdaniem współczesnych socjologów i pedagogów społecznych, katolicyzm polski zakorzeniony jest bardziej w warstwie obyczajowo kulturowej, niż w samej wierze. Sprzężony silnie z polską kulturą jest raczej znakiem przynależności do wspólnoty narodowej. Ów katolicyzm „,nawykowy” wyraźnie oddziela odświętne uczestnictwo w praktykach religijnych od zasad, jakimi Polacy kierują się w życiu codziennym ${ }^{31}$. Postawa taka powoduje ro-

27 Zob. P. M. Zulehner, H. Denz, Wie Europa lebt und Glaubt. Europäische Wertestudie, Düsseldorf 2003, s. 16-25; J. Mariański, Religijność społeczeństwa polskiego w perspektywie europejskiej. Próba syntezy socjologicznej, Kraków 2008.

28 J. Tischner, W krainie schorowanej wyobraźni, „Znak” 500 (1997), s. 205.

29 Tamże, s. 207.

${ }^{30}$ Por. J. Mariański, Kościół ludowy w poszukiwaniu nowej tożsamości społecznej, „Znak” 500 (1997), s. 41.

${ }^{31}$ E. Wnuk-Lipiński, Nadmierne nadzieje, nadmierne obawy. Czy integracja Europy zagraża Kościołowi?, „Tygodnik Powszechny” 4 (2006). 
dzaj schizofrenii społecznej, charakterystycznej właśnie dla społeczeństwa w dobie pluralizmu, jak również dla epoki przejścia między tradycją a ponowoczesnością.

W takiej sytuacji polskie społeczeństwo, a zwłaszcza polska młodzież, wymagają, używając słów zmarłego papieża Jana Pawła II, gruntownej, nowej ewangelizacji, zwróconej w naszej polskiej rzeczywistości ku wartościom ewangelicznym, wartościom wobec Chrystusa i jego Kościoła ${ }^{32}$.

Przestrzenią, na której głównie manifestuje się religia jako sfera $s a$ crum jest naturalnie Kościół instytucjonalny, ale edukacja religijna realizuje się także $\mathrm{w}$ rodzinie $\mathrm{z}$ racji przysługującego rodzicom prawa naturalnego i w szkole, jako instytucji działającej in loco parentis. Z tych też względów dom rodzinny i szkoła należą nadal do podstawowych instytucji wychowawczych, w tym także wychowania religijnego. Chcąc sprostać wyzwaniom współczesnego pluralizmu, powinny one poszukiwać spójności aksjologicznej i metodologicznej, a w zakresie kształtowania zachowań religijnych, bardziej wspólnotowego i bardziej funkcjonalnego modelu życia. Niezależnie bowiem od kryzysu, jaki dostrzega się na gruncie polskiej religijności i w edukacji religijnej, to ona pozostaje w swych skutkach prawdziwym faktem pedagogicznej dojrzałości wychowawców.

W kształceniu, a więc także kształceniu religijnym, nie powinno się rezygnować z prawa do wyrażania podzielanych wartości i znaczeń. Kształcenia nie można bowiem zawęzić do przekazywania obiektywnych informacji i formowania wystandaryzowanych kompetencji. Kształcenie jest przecież formą dialogu, w którym uczestniczące strony nie tylko przekazują informacje, lecz również ujawniają i urzeczywistniają wobec siebie wartości. I właśnie dlatego należy się opowiedzieć po stronie takiej wizji edukacji, która - przekazując obiektywne informacje i kompetencje - nie rezygnuje z konfrontowania $\mathrm{z}$ wielością znaczeń, a jednocześnie wzmacnia tożsamość i wspomaga kształtowanie poglądów uczniów.

Współcześnie już nikogo nie dziwi brutalizacja życia szkolnego, nonkonformizm i erupcja emancypacji. $Z$ dużą pewnością można przypuszczać, iż przyczyną takiego stanu rzeczy jest kryzys człowieka i jego tożsamości oraz zaburzenie możliwości porozumienia w sytuacji wzrastającej pluralizacji i przypadkowości życia jako efektu procesów modernizacyjnych. Dzisiejsze społeczeństwo „tempa”, „przygodności”, „ryzyka” powinno w imię przeciwdziałania własnemu rozpadowi, zachować z jednej strony obszary służące identyfikacji jednostek, $\mathrm{z}$ drugiej natomiast pielęgnować zdolności służące dialogowi i porozumieniu. Taką rolę może spełniać projekt efektyw-

32 Przestanie Jana Pawła II do Konferencji Episkopatu Polski „, Wspólnota jest owocem wiary”, „Tygodnik Powszechny” 25 (1997). 
nej relacji między Kościołem i religią, a edukacją, wpisując się dialogicznie w egzystencję ludzką.

Jak próbowałem dowieść w powyższym tekście, edukacja religijna realizuje najpełniej rozwój osobowy człowieka, połączony z pozytywną koncepcją jego wolności i z określonym wyobrażeniem dialogu. Współczesna szkoła w swej działalności wychowawczej nie może pomijać zatem wartości mających swe źródło w religii i przynależnych do sfery sacrum, niezależnie od pluralizmu światopoglądowego. Bowiem to nie sankcje zawarte implicite w normach społecznych i przepisach prawa, ale religijny i moralny nakaz sumienia, lub jeśli kto woli przymus wewnętrzny, jest pewniejszą, choć wcale nie łatwiejszą drogą do respektowania podstawowych zasad moralnych ${ }^{33}$. Warto przypomnieć, że już w latach międzywojennych Sergiusz Hessen dostrzegał w wychowaniu religijnym i w głosie sumienia jedyną drogę do uzyskania przez jednostkę autonomii moralnej. Mówił: „Wychowanie wymaga przede wszystkim osobistego i wolnego udziału wychowanka w duchowych wartościach i dlatego nie może istnieć bez swobodnego wysiłku osobistego sumienia wychowanka"34. O istocie wychowania rozstrzyga bowiem samowychowanie się jednostki ludzkiej dążącej do tego, by stać się autonomiczną osobowością ${ }^{35}$.

\section{Plus ratio quam vis. The proposal of modern education - religion dialogue (Summary)}

The main aim of this article is to present a proposal of modern education religion dialogue; an attempt to answer a question - how contemporarily religious education should look like. In a religious education, which can be described as "the one which comes out of a man and is focused on a man", a central point of educational process is a man indeed. At the basis of presented conception lies a famous maxim of a great learned Paweł Włodkowic - Plus ratio quam vis, the motto which later has been taken over by many European Universities as a credo of its academical activity. This maxim literally can be understood as: More reason than strength. The author refers to the classic anthropology and affirms that today's

${ }^{33}$ Por. W. Flitner, J. Derbolav, Problemi di etica pedagogica, Brescia 1988; J. Mariański, Religia i Kościót w społeczeństwie pluralistycznym, Lublin 1995.

${ }^{34}$ S. Hessen, Poglad na świat a pedagogika, „Kultura i Wychowanie” 193 (1933), s. 131; S. Rosik, Sumienie między wolnościq a prawda, w: J. Nagórny, A. Deredziuk (red.), Człowiek - sumienie-wartości, Lublin 1997, s. 103-120.

${ }^{35}$ Por. tamże; W. Pannenberg, Antropologia in prospettiva teologica, Brescia 1997. 
society of "pace", "adventure" and "risk", in the name of counteraction of it's own break-up should protect the fields of individuals' identification and, on the other hand, should cherish the ability of dialogue and understanding. This can be achieved by the project of effective relation between Church, religion and education, in order to leave "dialogique" trace in human existence. 